Received: 16 February 2019

Revision received: 2 June 2019

Copyright $\odot 2019$ ESTP

Accepted: 20 June 2019

www.estp.com

DOI 10.12738/estp.2019.3.003 • July $2019 \cdot 19(3) \cdot 33-48$

Article

\title{
Media Competence in Spanish Secondary School Students. Assessing Instrumental and Critical Thinking Skills in Digital Contexts
}

\author{
Amor Pérez-Rodríguez \\ University of Huelva, Spain \\ Pilar Marín-Mateos \\ University of Huelva, Spain
}

\author{
Agueda Delgado-Ponce \\ University of Huelva, Spain \\ Luis M. Romero-Rodríguez \\ Universidad Espíritu Santo, Ecuador
}

\begin{abstract}
The ways in which young people communicate have changed in line with the impact of technologies. This change has been accompanied by growing differences between the young, and their "liquid" experience, and adults with their "solid" experience, and these shapes the state of the question that defines young people as digital natives. This work analyses Spanish adolescents' level of media competence. The sample consisted of 672 students attending secondary schools in 10 provinces in Spain. The average age of the participants was 14 . The study aims to show that, although today's adolescents are described as the digital generation, and there is a widely held belief that they are digital natives, their level of media competence is low and there is need for fomenting greater literacy skills in this field. The ad hoc questionnaire yielded results that indicate an overall medium level of media competence, but a skills shortage in the dimensions relating to critical thinking, such as in reception and audience, production and programming processes, and ideology and values. The conclusions question the supposed superior competence of digital natives in media. This study underlines the need for a clear definition of the concept of media competence from a convergence perspective.
\end{abstract}

\section{Keywords}

Media competence $\bullet$ media literacy $\bullet$ secondary education $\bullet$ teaching/learning strategies $\bullet$ critical thinking $\bullet$ digital context

\footnotetext{
This research is part of the work carried out by the Alfamed group (Euro American Interuniversity Network for Research on Media Competences for Citizens), with the support of the Coordinated I+D+I Project called "Citizens' Media Competences in emerging digital media (smartphones and tablets): innovative practices and edu-communication strategies in multiple contexts" [MINECO/FEDER\#1] under Grant [EDU2015-64015-C3-1R]; and of the "Media Education Network" of the State Program for the Promotion of Excellence in Scientific-Technical Research, the State Subprogram for Knowledge Generation the [MINECO/FEDER\#2] under Grant [EDU2016-81772-REDT].

Correspondence to Amor Pérez-Rodríguez, PhD, Department of Philology, University of Huelva. Campus de «El Carmen», Avda. de las Fuerzas Armadas, S/N. 21007, Huelva, Spain. E-mail address: amor@uhu.es

Citation: Pérez-Rodríguez, A., Delgado-Ponce, A., Marín Mateos, P., \& Romero-Rodríguez, L. M. (2019). Media Competence in Spanish Secondary School Students. Assessing Instrumental and Critical Thinking Skills in Digital Contexts. Educational Sciences: Theory \& Practice, 19(3), 33 - 48. http://dx.doi.org/10.12738/estp.2019.3.003
} 
The communication habits and behaviours of young people have undergone considerable change in recent years in line with advances in media and technology. Many studies testify to this fact, spawning labels (Helsper \& Eynon, 2010) that have stuck, or come and gone, that try to fix the identity of young people operating within this changing environment. Terms such as the Net Generation (Tapscott, 1999), the Millennials (Howe \& Strauss, 2000), the Digital Generation (Prensky, 2001), the Interactive Generation (Bringué \& Sádaba, 2009) and the Liquid Generation (Area \& Ribeiro, 2012; Bauman, 2004), have sought to define young people and their experiences and relations with digital media. This boom in teenage online activity shows that media and the Internet are now far more than just tools for disseminating information because the mechanisms for production, storage, access and dissemination have changed beyond recognition. Nearly all forms of cultural expressions have been disrupted along with the interactions, communication situations and the languages that make them possible. We tend to think that today's young people are different from adults because they have grown up surrounded by all these media and technology. "Today's kids are so bathed in bits that they think technology is part of the natural landscape" (Tapscott, 1999, p. 2). Prensky (2001, p. 1) adds that "computer games, email, the Internet, cell phones and instant messaging are integral parts of their lives".

The high degree of ownership and unlimited access to technological devices offers adolescents a new way to occupy time, share experiences, school and social life (Bringué \& Sádaba, 2009). The main divide between today's youth and adults relates to this "liquid" experience, to use Baumann's (2013) metaphor, as opposed to what Area and Ribeiro (2012, p.14) termed the "experience of consumption and acquisition of the solid culture". Therefore, from an educational perspective, significant changes should be considered in terms of competences, skills and interests from a communicative standpoint. However, this adult-adolescent divide can fall victim to stereotypes, myths and generalities (Cabra-Torres \& MarcialesVivas, 2009) and be subject to less than rigorous analyses that fail to take into account other variables (Bennet, Maton, \& Kervin, 2008; Rowlands, Nicholas, Williams, \& Huntington, 2008).

The complex change in communication processes, access to, and processing of information which undoubtedly affect the entire population, has shaped the state of the question in terms that have a far more popular bias than scientific, "debates about change must be based on empirical evidence and not rhetoric" (Helsper \& Eynon, 2010, p. 518). Although by no means proven, digital technology has revolutionised the educational environment. Young people "will need a broad range of skills, including cognitive and metacognitive skills (e.g., critical thinking, creative thinking, learning to learn and self-regulation), social and emotional skills (e.g., empathy, self-efficacy and collaboration), and practical and physical skills (e.g., using new information and communication technology devices)" (OCDE, 2018, p. 5). However, the skills required in the media and communication context in which young people operate goes far beyond the merely digital (Lee, Chen, Li, \& Lin, 2015; Leurs, Omerović, Bruinenberg, \& Sprenger, 2018; Scolari, 2018).

\section{Media Education, Digital and Media Competence}

In the past, the concepts of information, audio-visual and digital literacy were clearly differentiated. Information literacy centred on access, treatment and conversion of information into knowledge (Bawden, 2001; McClure, 1994) while audio-visual literacy referred to the knowledge, skills and attitudes related to mass media and audio-visual language (Masterman, 1993). As technologies developed, digital literacy became defined as the capacity to search for, process, communicate, create and disseminate information through technologies (Bawden, 2001; Eshet, 2004). However, the tendency towards confluence of media on the Net, and its subsequent digitalization, has led to the need to define approaches more clearly (Buckingham, Banaji, Carr, Cranmer, \& Willett, 2005; Fedorov \& Levitskaya, 2015; Hobbs \& Jensen, 2009; 
Potter, 2010), and to convergence and terminological and conceptual integration (Celot \& Pérez-Tornero, 2009; Ferrés \& Piscitelli, 2012; Gutiérrez \& Tyner, 2012; Hobbs, 2010; Koltay, 2011; Livingstone, 2004; Moeller, Joseph, Lau, \& Carbo, 2011; Pérez-Rodríguez \& Delgado-Ponce, 2012; Pérez-Tornero \& Martínez-Cerdá, 2011).

In Europe, the concept of media competence goes beyond instrumentalization and decoding. Other capacities that support media reading and writing processes in broader semiotic and pragmatic contexts, especially in culture and social interaction, have become more prominent (European Commission, 2007). Media competence embraces capacities related to coding and decoding, techno-instrumental skills, and skills in interpretation and culture, which involve several literacy forms and abilities. Media literacy is defined as:

The skill to access, analyse and evaluate the power of images, sounds and messages that we face as we go about our daily business, and which are an important part of our modern-day culture, as well as the skill to communicate in a competent way through the media available to us. Media literacy refers to all media supports, including film and television, radio, music, the press, Internet, and any type of digital technology designed for communication (European Commission, 2007, p. 4).

UNESCO's Media and Information Literacy Curriculum and Competence Framework systematized media literacy referring to the functions of media and the commitment to self-expression, as well as access, evaluation, and ethical use of information. For the United Nations Alliance of Civilizations (UNAOC), the key concept lies in the development of critical thinking in the face of mass media messages and the production of media messages, which have increased considerably due to greater participation sparked by the arrival of Web 2.0. The idea of media competence derives from the convergence of audiovisual and digital competence in an environment of omnipresent media, "a world of media convergence" in which "all the important stories are told, all the brands are on sale, attracting all the consumers via multiple media platforms" (Jenkins, 2008, p. 14). Therefore, competence in media needs to transcend the possession of the skills required for using devices and machines, or the absorption by the new emerging media of the old. Its essence, in the literacy setting, in terms of education in media and communication, is rooted in the increasingly complex interactions of old and new media (De-Casas-Moreno, Tejedor-Calvo, \& RomeroRodríguez, 2018; Yildiz, Durak, \& Saritepeci, 2019). Especially because "the convergence occurs in the minds of the individual consumers and through their social interactions with others" (Jenkins, 2008, p. 15). Considine, Horton, and Moorman (2009, p. 473) insisted on the responsibility "to build a bridge between the knowledge students already have and the content that they need to learn to be successful inside and outside of school". Gutierrez and Tyner (2012) consider that we have to put aside the differences between media education and digital competence and bring them together.

\section{Dimensions for Conceptualizing Media Competence}

Providing a precise definition of media competence is complex, as numerous authors testify (Martens, 2010; Mason \& Metzger, 2012; Potter, 2010). It is fundamentally a question of approach, or perspective, which is strategic in nature and involves prioritizing certain aspects over others. Mason and Metzger (2012) set out four paradigms that emphasized the rational and intelligent use of media for personal and social benefit, expressed as New Media Literacies; the power of media to manipulate users and the importance of learning strategies to enhance critical analysis, known as Critical Media Studies; practices, general trends in society and perspectives of the world that condition images, and the uses of media and technology, known as Medium Theory; and the Pragmatist, a person who establishes connections between 
social and technological changes in order to strengthen society's ability to construct a stronger participatory democracy.

Setting limits and fixing specific indicators to mark out the field of analysis is also complicated. This is evident in the numerous proposals that derive from various theoretical positions, from recognition of the need for literacy in new media based on traditional literacy, skills in research, techniques, and critical analysis (Jenkins, Purushotma, Weigel, Clinton, \& Robison, 2009), to the vision sustained by Mason and Metzger (2012, p. 446) of "affirmative practices that generate space for common meaning-making and inclusive discourses". We agree with Hobbs (2010) in that these are not approaches that overlap or compete, rather they respond to a process of adaptation to needs. As Potter (2010) points out, the ever-changing nature of media messages means that the learning process is never-ending. In this sense, Kellner \& Share (2005) emphasize that media competence involves analytical skills to deconstruct media codes and conventions, abilities to critically assess stereotypical representations and dominant ideologies, as well as interpretative capacities towards the diverse meanings and narratives present in media texts. Different studies such as Buckingham (2003), Celot and Pérez-Tornero (2009), Chen, Wu, and Wang (2011), Ferrés (2007), Hobbs (2010), Jenkins et al. (2009), Lee et al. (2015), Leurs et al. (2018), Martens (2010), Pérez-Rodríguez \& Delgado-Ponce (2012), and Pérez-Tornero (2013) have defined the dimensions, indicators and skills needed for the acquisition of competences in the face of new media ecosystems. Today, media competence involves "access, analysis, evaluation, critique, production and/or participation with media content" (Lee et al., 2015, p. 85).

This study uses the following dimensions devised by Ferrés (2007) to conceptualize media competence: Language, knowledge of the codes used in the construction of audio-visual messages, and a capacity for analysis and expression according to the communicative situation; technology, the capacity to utilize tools and devices that make communication possible; reception and audience, the concept of audience and active reception in relation to screens; production and programming processes, knowledge of the functions assigned to the main production agents; ideology and values, the capacity to produce messages that transmit values and contribute to the improvement of the social environment; aesthetics, analysis and evaluation of audio-visual messages from an aesthetic standpoint and its relation to other forms media and artistic output. We consider these dimensions established by means of different studies (Ferrés et al., 2011; Ferrés, Aguaded, \& García Matilla, 2012; Masanet, Contreras-Pulido, \& Ferrés, 2013; Pérez-Rodríguez, Ramírez García, \& García-Ruiz, 2015; Ramírez \& González, 2016) carried out on the Spanish population in different areas and age ranges, the basis of our concept of media competence.

\section{The present study}

This work aims to evaluate the level of media competence of secondary school students in Spain based on a systematization of this key concept for communicative competence. The results are part of a research project financed by the Spanish government. The central hypothesis of this study aims to show that, although today's adolescents are described as the digital generation, and there is a widely held belief that they are digital natives, their level of media competence is low and there is a need to promote greater literacy skills in this field. The specific aims of this research are as follows: (i) to identify the level of media competence in secondary school students; (ii) to find links between the dimensions, and discover the extent of their development in the students surveyed; (iii) to identify the incidence of demographic variables in the levels of media competence. 


\section{Methods}

\section{Participants}

The sample consisted of 672 students attending secondary schools in 10 provinces in Spain (Cantabria, Córdoba, Huelva, Granada, La Rioja, Lugo, Málaga, Murcia, Sevilla, and Valencia). The selection was nonprobabilistic, established according to the following criteria: The authorization to administer the questionnaire in the educational centres, the differentiation of educational stages and the heterogeneity of the centres (public, subsidized and private). The age range of the participants in percentage terms was 14-year-old (42.56\%), 15-year-old (41.35\%), 16-year-old (12.03\%) and 17-year-old (4.06\%). All students were in the fourth year of their secondary school education. Gender-wise, $50.38 \%$ were female and $49.62 \%$ male. The students were matriculated in state schools $(71.58 \%)$, private state-funded schools $(24.06 \%)$ and private schools $(4.36 \%)$.

\section{Instruments}

An ad hoc questionnaire (http://goo.gl/sd1P27) was used to conduct the research based on the dimensions established by Ferrés (2007) and validated by the Delphi technique, with 15 participating experts following the phases proposed by Bravo and Arrieta (2005), which involved the reformulation and removal of some initial questions. The same was done in other studies from the same project (Pérez-Rodríguez et al., 2015; Ramírez-García \& González-Fernández, 2016). Before the questionnaire was submitted, a pre-test was carried out on an experimental group in order to test how the instrument would function in the field.

The questionnaire consisted of 19 indicators that corresponded to the six dimensions selected. Students' level of media competence was measured according to the responses to 25 multiple-choice questions that were both objective and subjective in nature. The questions were subdivided to obtain 39 items. Media competence was measured by interpreting the responses to the various items on a scale of 1-3 (where 1 is the lowest value and 3 is the highest value) according to the extent to which the participant believed he/she was competent in that dimension.

Table 1. Media competence, indicators and measurement standards

\begin{tabular}{|c|c|c|c|c|c|}
\hline & & & Scale & & \\
\hline Dimension & Indicator & Item & 1 & 2 & 3 \\
\hline \multirow[t]{3}{*}{ Language } & $\begin{array}{l}\text { Understanding the information transmitted by differ- } \\
\text { ent codes and languages. }\end{array}$ & 11 & No & In some cases & Yes \\
\hline & $\begin{array}{l}\text { Capacity to interpret and evaluate the different codes } \\
\text { of representation, and the function they perform in the } \\
\text { message. }\end{array}$ & 12 & 2 and 5 & 1,3 or 4 & $1,3,4$ \\
\hline & $\begin{array}{l}\text { Capacity to express oneself through a range of repre- } \\
\text { sentation and signification systems. }\end{array}$ & 23 & No & & Yes \\
\hline \multirow[t]{2}{*}{ Technology } & Knowledge of tools used to surf the Net. & 7.1 & 1 and 2 & 4 and 5 & 3 \\
\hline & $\begin{array}{l}\text { Knowledge of different technological tools to get in- } \\
\text { formed and to communicate. }\end{array}$ & 16 & $<3$ & $3-5$ & $>5$ \\
\hline \multirow{4}{*}{$\begin{array}{l}\text { Reception and } \\
\text { audience }\end{array}$} & Capacity to evaluate the cognitive effects of emotions. & 15 & 1 or 4 & & 2 or 3 \\
\hline & $\begin{array}{l}\text { Capacity to recognize the influence that media have } \\
\text { on us. }\end{array}$ & 15.1 & No & Maybe & Yes \\
\hline & $\begin{array}{l}\text { Capacity to recognize the influence that media have } \\
\text { on others. }\end{array}$ & 15.2 & No & & Yes \\
\hline & $\begin{array}{l}\text { Capacity to discern and manage disassociations that } \\
\text { sometimes occur between feelings and opinions, and } \\
\text { emotions and reason. }\end{array}$ & 15.3 & 1,4 & 3 & 2 \\
\hline
\end{tabular}


Knowledge of the level of social responsibility required.

Capacity to select, review and self-evaluate one's own media diet in accordance with criteria that show awareness and a reasonable balance.

Production and programming processes

Ideology and values

Aesthetics
Knowledge of the role of media production professionals.

Knowledge of the phases of the production processes and the infrastructure required by users to make their own productions.

Skills to search for, organize, contrast, prioritize and synthesize information deriving from different systems and settings.

Skills to search for information deriving from different systems and settings.

Capacity to assess the reliability of information sources, drawing critical conclusions from what is said and what is omitted.

Capacity to make the best use of the tools of the new communication environment in order to be able to commit to culture and society as responsible citizens. Capacity to detect the intentions and interests that lie behind corporate and popular productions and their ideologies and values, be they explicit or hidden, by adopting a critical attitude towards them.

Sensitivity to recognize a media production that falls short of the minimum standards of aesthetic quality.

\begin{tabular}{|c|c|c|c|}
\hline 18 & No & $\begin{array}{l}\text { I will make } \\
\text { It, but I don't } \\
\text { know how }\end{array}$ & Yes \\
\hline 21 & No & Sometimes & Yes \\
\hline 17 & $<3$ & $4-5$ & $>6$ \\
\hline 25 & $\begin{array}{l}\text { Incorrect } \\
\text { order }\end{array}$ & One failure & $\begin{array}{l}\text { Correct } \\
\text { order }\end{array}$ \\
\hline 8 & 1 & 3 & 2 \\
\hline 9 & 1 & 2,3 and 4 & 5 and 6 \\
\hline $\begin{array}{l}10, \\
10.1\end{array}$ & 1 and 5 & & 2,3 and 4 \\
\hline $\begin{array}{l}20, \\
20.1\end{array}$ & No & & Yes \\
\hline 22 & $\begin{array}{l}2,3,6,7, \\
8\end{array}$ & 5 & 1,4 \\
\hline $14.1 \mathrm{~A}$ & 3 & 6 & $1,2,4,5$ \\
\hline 14.1B & 5 & 3 & $1,2,4,6$ \\
\hline
\end{tabular}

Validating the construct. Exploratory factor analyses (EFA) were first carried out to generate the theoretical constructs. The dimensions were conclusive, and the items showed significant leanings in the four proposed variables. The EFA indicated an explained variance of $66.83 \%$, the Kaiser-Meyer-Olkin measure of .93, and significant Bartlett's test of sphericity $\left[\chi^{2}(190)=63854.763, p<.001\right]$. Cronbach's alphas were used to validate the internal consistency of the instrument and all were above .70 . Nunnally and Bernstein (1994), and Peterson (1994) state that this reliability coefficient must lie between .70 and .90 , while Garson (2013) declares that any figure above .60 is acceptable for exploratory purposes, and .70 for confirmatory objectives.

\section{Procedure}

The chosen design for the study was descriptive transactional in order to describe a phenomenon and analyse its incidence at a specific time (Hernández, Fernández, \& Baptista, 2006). The quantitative data were derived from a survey administered between November 2015 and February 2016. Researchers approached schools and explained the objectives of the study to obtain permission to conduct the fieldwork at each school. All participants were duly informed of the objectives of the research, and their informed consent was expressly obtained. The treatment of data was carried out in an internal computer platform from the University of Huelva that guarantees participants' privacy and anonymity, including the encrypted record of their e-mails and IP addresses. 


\section{Data analysis}

Once surveying was completed, data was processed and uploaded to SPSS (v.18) for analysis. Answers were categorized according to the previously designed assessment rubric for the survey. Data analysis was conducted using descriptive statistics followed by central and dispersion-tendency measures. The percentile measure was also used to determine media competence levels between different groups of participants.

\section{Results}

\section{Identifying Levels of Media Competence in Secondary School Students}

The global results show that the majority of students surveyed (72.2\%) have a medium level of media competence, as Figure 1 shows, based on the mean of the various dimensions. The students showed greatest competence in the dimensions of language and technology (65.80\% and 64\%, respectively) but were less skilled in the dimensions of reception and audience, ideology and values, and production and programming processes.

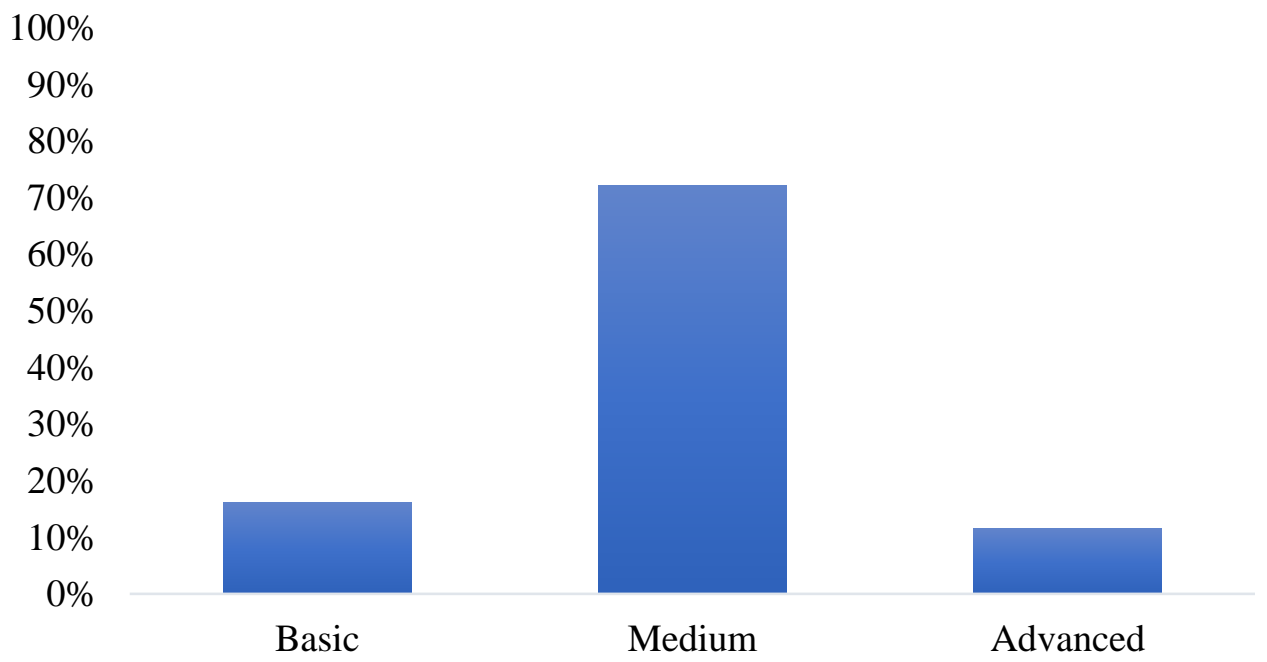

Figure 1. Level of media competence

In language, the dimension that covers knowledge of the codes used in the construction of audiovisual messages and the capacity for analysis and expression according to the communicative situation, $61.70 \%$ of the participants stated that they understood the information transmitted by the codes and languages (images, words, sound and music, among others) that constitute media messages. However, when questioned about the meaning these languages transmit in a short film sequence, only $14.1 \%$ answered correctly, and $67.20 \%$ were unable to construct a visual sequence without errors. On the other hand, $71 \%$ stated they had edited or manipulated images, videos and music using computer programs.

Technology, which refers to the use of the tools and devices that make communication possible, is one of the most developed dimensions in the students surveyed (64\%). The data revealed that $55 \%$ of students select a particular search engine for its speed and intuitive responses, $22 \%$ choose the one they consider the best and the rest do not look beyond the computer's preinstalled search engine. A high percentage 
is also familiar with the current array of technological tools: YouTube (81.2\%), Google Docs (63.7\%), iPad $(83.7 \%)$, Spotify (62.5\%). Only $29.4 \%$ were able to recognize the lens from a camera, as an example of an analogical instrument.

The other dimensions used to establish the level of media competence were developed to a lesser extent. In reception and audience, $28.9 \%$ of participants registered an advanced level of competence. It is significant that only $23.5 \%$ were able to identify the influence of advertising on emotions. However, one interesting aspect is young people's involvement as an active audience given that $42.3 \%$ state they have denounced or complained about images, videos or information to the appropriate authorities, and $15.6 \%$ say they would do so if they knew where and how to do it. In production and programming processes, $81.7 \%$ had a low level of competence, highlighted by the lack of knowledge of media professions $(66.75 \%)$ and a skills shortage in the field of production, indicated by the paltry $0.7 \%$ of students who said they were able to construct a visual sequence correctly. The students also scored low in ideology and values, with $74.6 \%$ ranked as basic level. Indeed, when it comes to detecting intentions and underlying interests in corporate and popular productions and their ideology and explicit and latent values, only $11.9 \%$ showed a capacity for critical thinking and demonstrated that they possessed a suitable scale of values.

The analysis of each dimension shows that these 14- to 17-year-olds are more developed in knowledge of media languages and controlling technologies but are not as strong in skills linked to reception and audience, and are lacking in skills in production and programming processes and dissemination, with a basic level in aspects related to ideology and values (Figure 2). The values obtained for the aesthetic dimension were discarded since they were deemed of dubious significance, the responses only corresponding to a single question in the questionnaire.

Dimensions of Media Competence

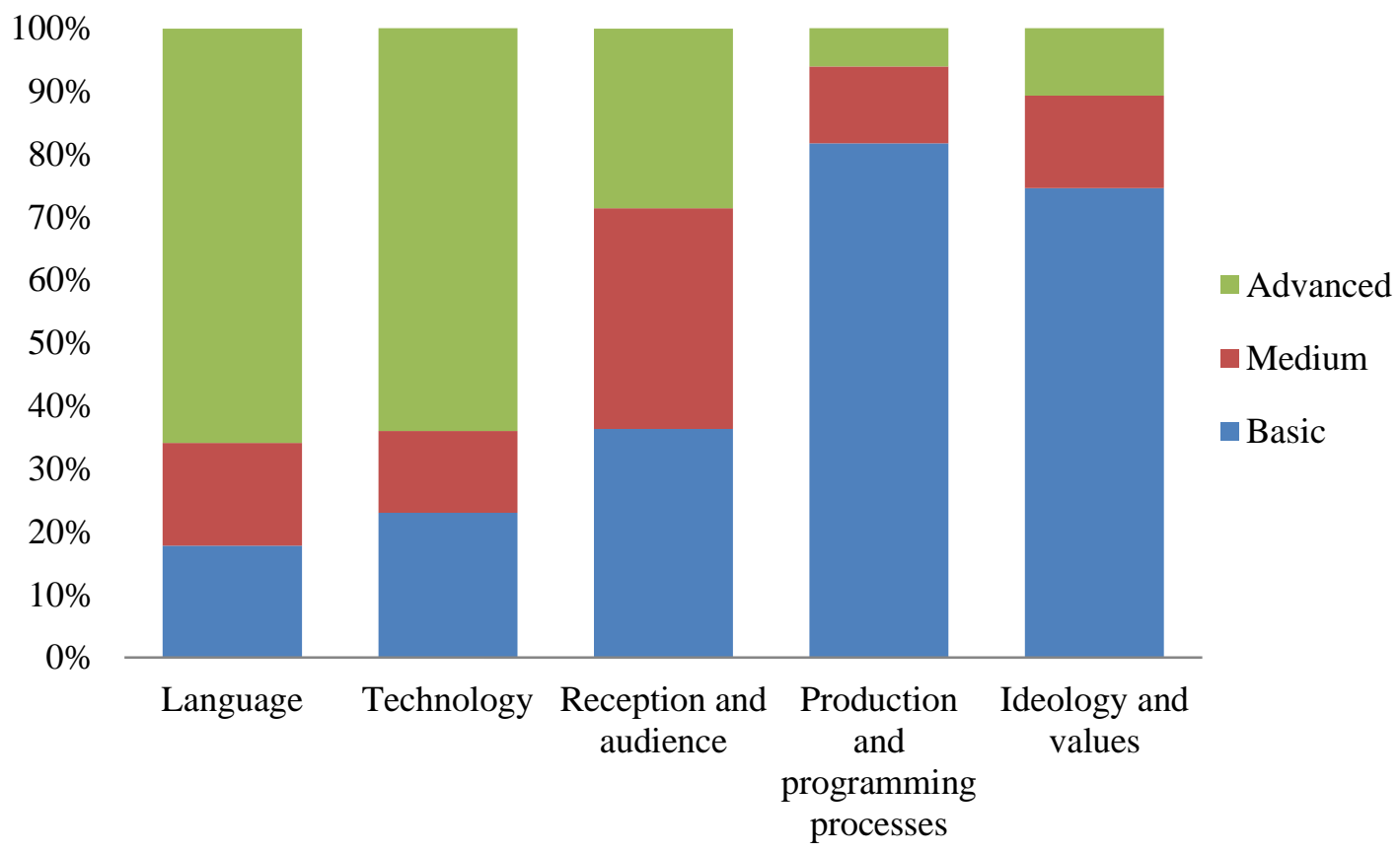

Figure 2. Level of development in dimensions 


\section{Links between Dimensions, and Discover the Extent of their Development in the Students Surveyed}

Cluster analysis determines, in a cumulative analysis, three groups within the sample studied. Successive partitions enabled us to define five groups on another level, the characteristics in both cases being similar.

(i) Cluster $1(f=122 ; 18.15 \%)$. The students in this group are better developed in the dimensions of technology, production and programming processes, and ideology and values. This group's dimensions are clearly indicated.

(ii) Cluster $2(f=268 ; 38.98 \%)$. The students in this group have well-developed competences in the dimensions of language, reception and audience, and to a lesser extent, production and programming processes. (iii) Cluster $3(f=282 ; 41.96 \%)$. This group has a very insignificant level of development in language, technology and ideology and values.

Data show that there are significant differences between group 1 and 3 in the levels of development in the dimensions of the research participants in each cluster.

A non-hierarchical $k$-means cluster test was applied and showed a high degree of coincidence with the previous analysis. So, group 1 is characterized by well-developed competence in the dimensions of technology, production and programming processes, and ideology and values, as occurs in cluster 1 . With similar characteristics, group 2 shows a high level of competence in reception and audience but is low in technology and ideology and values. The $k$-means tests show that group 1 and 2 are in opposition, with the dimensions of technology, production and programming processes, and ideology and values more developed in group 1 but less so in group 2. Group 3 presents no significant data in any dimension for the hierarchies and the $k$-means.

In relation to the second objective, these tests confirm the establishment of three groups of interrelated dimensions.

Table 2. Level of development in dimensions cluster analysis

\begin{tabular}{ccccccc}
\hline $\begin{array}{c}\text { Method } \\
\text { CLU3_2 Ward }\end{array}$ & $\begin{array}{c}\text { Language } \\
\text { ZMean }\end{array}$ & $\begin{array}{c}\text { Technology } \\
\text { ZMean }\end{array}$ & $\begin{array}{c}\text { Reception and } \\
\text { audience } \\
\text { ZMean }\end{array}$ & $\begin{array}{c}\text { Production and programming } \\
\text { processes } \\
\text { ZMean }\end{array}$ & $\begin{array}{c}\text { Ideology } \\
\text { and values } \\
\text { ZMean }\end{array}$ \\
\hline \multirow{2}{*}{1} & $n$ & 122 & 122 & 122 & 122 & 122 \\
& Mean & .64 & .39 & -.20 & 1.59 & 1.20 \\
2 & $n$ & 268 & 268 & 268 & 268 & 268 \\
& Mean & .35 & .55 & .06 & -.42 & -.02 \\
3 & $n$ & 282 & 282 & 282 & 282 & 282 \\
& Mean & -.61 & -.69 & .03 & -.28 & -.49 \\
\multirow{2}{*}{ Total } & $N$ & 672 & 672 & 672 & 672 & 672 \\
& Mean & .00 & .00 & .00 & .00 & .00 \\
\hline
\end{tabular}

\section{Identifying the Incidence of the Demographic Variables in the Levels of Media Competence}

According to the chi-square values, the three clusters from the hierarchical cluster analysis correlate to the type of educational centre and the education received, given that the significance is $\leq .05$. Of the students attending state schools, $46.2 \%$ are situated in group 3, in which development in some dimensions is insignificant. Group 2 contains $38.5 \%$ of state school students, who show development in the dimensions of language, reception and audience and, to a lesser extent, production and programming processes, and 
$15.3 \%$ are located in group 1, a cluster whose participants are the most competent across all dimensions. The students attending private schools, $44.8 \%$ present cluster 1 characteristics, $37.9 \%$ belong to cluster 2 and $17.3 \%$ to cluster 3 , a clear contrast to the figures for state school pupils.

In terms of the media education received, $77.1 \%$ of the students within group 1 (more developed in technology, production and programming processes and ideology and values) have received instruction in audio-visual or digital communication. In group 2, $75 \%$ of students have received some or a substantial amount of training in this area, while in group 3 the figure is $68 \%$. If we focus on those students who state that they have received quite a lot of training in this area, we see that $50 \%$ of them are part of group 2 (whose members are more developed in the language, and reception and audience dimensions).

If we analyse how the pupils have acquired this training, the majority $(n=211)$ state that they are self-taught. In group 2, 53.7\% say they learnt from friends or schoolmates and 40\% from workshops. In terms of the overall level of media competence, there is a correlation with the type of educational centre ( $p$ $\leq .05$ ). An analysis of the relation between these two variables shows that among all the private school students surveyed, $62.5 \%$ have acquired a medium level of media competence and $34.8 \%$ have an advanced level, with no private school student left behind on the basic level.

However, these media competence levels do not correlate with the degree of training, so it does not necessarily follow that the students in our survey who received more instruction in media had greater media competence.

\section{Discussion}

The results of the study provide evidence regarding the common view of adolescents as the digital, interactive or liquid generation and on their level of media competence. Their condition as digital natives (Prensky, 2001), moving easily within a context where the presence of the digital and its communicative uses and experiences is stronger by the day, has been demystified (Bennett et al., 2008; Bennett \& Maton, 2010; Cabra-Torres \& Marciales-Vivas, 2009; Correa, 2016; Helsper \& Eynon, 2010; Roy, Gareau, \& Poellhuber, 2018; Thompson, 2013). Although the uses of media and technology have changed the forms of communication, and affected aspects linked to adolescents' behaviour and motivation, for better and for worse (Areepattamannil \& Khine, 2017), teenagers' broad experience in digital does necessarily mean competence in media (Romero-Rodríguez, Torres-Toukoumidis, Pérez-Rodríguez, \& Aguaded, 2016).

The data gathered from the questionnaire reveal a higher level of development in the dimensions of technology and language, and it was observed that the students showed an awareness of the tool they use in their searches and its characteristics. Results showed that they are familiar with an array of technological tools that they can use to be informed and to communicate. This can be related to their condition of digital natives (Prensky, 2001; Tapscot, 1999; Roy et al., 2018) as they are able to identify technological and, to a lesser extent, analogical aspects. Yet high levels of exposure and frequency of media and technology use does not necessarily equate to a good level of media literacy (Johnson et al., 2014). Thompson (2013, p. 21), often evidenced by that fact "that when digital natives use a web search engine, they tend toward a get in, get the answer, get out approach". This idea of speed and high exposure to technological resources is at the heart of media competence shortfalls. This notion of the "telegram culture", of communicative immediacy as opposed to intellectual reflection (Area \& Ribeiro, 2012, p. 16).

The surveyed youth display a higher level of knowledge in terms of media languages and technology usage but are not as strong in skills linked to reception and audience and are lacking in skills in production and programming processes and dissemination, with a basic level in aspects related to ideology and values. In accordance with previous research (Bennet et al., 2008; Scherer, Rohatgi, \& Hatlevik, 2017), youngsters 
use technology more in their leisure spaces (e.g., YouTube, iPad, Spotify) at the instrumental level or "as a simple set of procedural abilities (a copy and paste literacy)" as suggested Calvani, Fini, and Picci ( 2012, p. 805). In this sense, $55 \%$ of the surveyed students select a search engine on the basis of its speed and intuitive responses, which reflects a prioritization of instrumental rather than intellectual motivations.

Although more than half the adolescents surveyed consider that they understand messages and can express themselves through a range of systems of representation and signification by editing and manipulating images, videos or audio with computer programs, their scant knowledge of the codes used to construct audio-visual messages is paradoxical, particularly considering the efforts made by authorities, administrations and government and educational institutions to develop these technological skills and their use in the classroom. In this sense, various authors with differing perspectives (Bennett \& Maton, 2010; Correa, 2016; Kellner \& Share, 2007; Kim, 2019; Kim \& Lee, 2013; Livingstone, 2012; Scherer et al., 2017; Thompson, 2013; Velagapudi \& Menon, 2018) all agree that there is still much to be done in the education system and policy-making initiatives to improve the level of media literacy. In this complex field of youngsters' experiences in the digital world (Bennet \& Matton, 2010), the influence of the use of technologies for communication has been positive (Areepattamannil \& Khine, 2017), especially if they promote significant learning experiences (Kim, 2019; Rohatgi, Scherer, \& Hatlevik, 2016; Velagapudi \& Menon, 2018). We agree with Van Deursen and Van Dijk (2010) in the need for the suitable development of technological skills, especially for youth to become active participants in the generation of content for serious rather than trivial purposes

The students' low level in key aspects such as competence in reception and audience, ideology and values, and production and programming processes points to the need to exploit the potential of media and ICT (Livingstone, 2012) for a literacy that can stimulate competent and more critical use (Buckingham, 2007; Calvani et al., 2012; Leurs et al., 2018; Masanet, Contreras-Pulido, \& Ferrés, 2013; Scolari, 2018). Johnson et al. (2014) consider that children and adolescents display deficient levels of digital competence, particularly in terms of critical thinking and participation, meaning students interact with content and are active in generating original responses to this content.

Our analyses reveal differences between the teenagers and their level of media competence, and in the development of, and relations between, the dimensions in this study. Our study has established profiles of students that are differentiated, in line with several authors (Bennett et al., 2008; Correa, 2016; Helsper \& Eynon, 2010; Kim \& Lee, 2013; Thompson, 2013) who question the idea that digital natives are a homogenous group. Scherer et al. (2017) found differences in terms of proposals and the context, among others, and insist on the need to take account of these differences in the educational context. In our study, the differences in levels of competence are defined in three groups, of which the third group provides no significant data on level of competence. The first group displays greater development in the dimensions of technology, language, production, and programming (García-Ruiz, Ramírez, \& Rodríguez, 2014). We agree with Calvani et al. (2012) who argued that the range of ICT skills in adolescents lacks homogeneity in terms of advanced cognitive and technological abilities. This group is clearly different from group 2, a bigger set with higher levels of competence in language, technology, and reception and audience. Although the indices are by no means high, it is significant that the best-developed dimensions are language, technology, and reception and audience. Kellner and Share (2007) considered that the perception of technological neutrality and an emphasis on instrumental skills have created a gap in the educational system that is very favourable for the development of critical media literacy. Likewise, Gutierrez and Tyner (2012) warn of the risk of narrowing digital competence to its technical and instrumental aspects and overlooking principles and attitudes. The results of our study showed that it is fundamental to strengthen those skills related to reception 
and audience, production and programming processes, and ideology and values, as has also been highlighted by Leurs et al. (2018), and Scolari (2018). Kellner and Share (2007) state that critical media literacy becomes essential in the face of a lack of critical thinking in analytical and productive processes within educational institutions, paired with rapid and vast technological advances and globalization. The processes of literacy are, therefore, vital for the development of media competence (Gutiérrez \& Tyner, 2013; Masanet et al., 2013; Pérez-Rodríguez et al., 2015; Ramírez-García, \& González- Fernández, 2016). The data showed that the incidence of media education was positive (Kim \& Lee, 2013).

The current school curriculum in Spain considers digital competence as one of the key competences to be developed, in line with other European countries, but we consider that this is insufficient given the results (Helsper \& Eynon, 2010; Ramírez-García \& González-Fernández, 2016). The differences revealed by the fact that the students from private schools form a majority in groups 1 and 2, with medium and high levels of media competence, are partly explained by the instruction in media they have received, although there is no clear correlation. It is significant that the majority $(n=211)$ state that they are self-taught or have been helped by the peers or have learnt about media in workshops outside school. As Potter (2004) suggested acquiring knowledge or skills by itself does not indicate media literacy.

Our study reaffirms the need for education in media literacy from a convergence perspective that goes beyond the treatment of the impact of technology to engaging with skills that can promote understanding, critical thinking, creativity, intercultural awareness, and citizenry, as recommended UNESCO. Mason and Metzger (2012) argued that media education should focus on the effects of new media on perceptions and understandings, making it important to integrate in the school curriculum the development of learning skills oriented to the cognitive process, communication and skills to resolve problems, and tools for learning that include ICT (Hobbs, 2010; Kim, 2019; Roy et al., 2018). This also means accepting the concept of media competence that goes beyond the merely instrumental and access to technological resources, as suggested by Potter (2010), who considered media literacy as a twofold endeavour: constructing knowledge and cultivating abilities.

We agree with Gutierrez and Tyner (2012) when they said that current advances in technology and high rates of exposure to new devices that multiply available resources and boost the potential for communication can unconsciously deflect us in the direction of merely descriptive and technical aspects of media education focused on device management and usage. This would partly explain the results obtained, which show that the way schools deal with technology is not so beneficial for learning (Kim, 2019; Livingstone, 2012; Thompson, 2013; Velagapudi \& Menon, 2018).

There is also an evident need to enhance skills related to critical thought, and in the cognitive, ethical and aesthetic areas (Calvani et al., 2012; Kellner \& Share, 2007; Martens, 2010; Mason \& Metzger, 2012; Scolari, 2018). We highlight here the importance of strengthening literacy skills by considering the communication experiences youngsters have outside school (Bennet et al., 2008; Rohatgi et al., 2016; Scolari, 2018). The need to develop knowledge, skills and attitudes for life and work in the face of the impact of media and technologies in society is increasingly urgent. In particular, the critical assessment of the messages, participation and democratic expression, and the skills required to produce user-generated content (De-Casas-Moreno et al., 2018; Leurs et al., 2018; Ramírez-García \& González-Fernández, 2016).

International Organizations (such as UNESCO, ONU, UNICEF, European Council, European Parliament) stress the urgency of promoting media competence in the face of digital convergence. We believe it is vital to address the lines of convergence between the uses of technology and the audio-visual world, and the processes of understanding, production and interpretation that they involve, in order to produce a concept of media competence that enables young people to acquire a solid grounding in media 
literacy. In this sense, it would be important to provide training on the ways, media and formats in which contents are created and received, the new narratives, the contexts of reception, interaction and production, the processes for producing and receiving critically, the creativity and aesthetics of the productions (PérezRodríguez, Contreras-Pulido, \& Delgado-Ponce, 2018). Although this study is not considered conclusive, it offers a perspective that is focused on specific aspects of each dimension of media competence in the secondary school students in Spain, as part of a survey of different sectors of the Spanish population. It will be necessary to analyse all the established indicators and propose instruments that provide qualitative data in line with the skills required in the current context to be competent in a transmedia context. Future research should focus on the ways in which students read and write, including their strategies to produce texts and a deeper understanding of the types of texts they employ to communicate in today's liquid society.

\section{References}

Area, M., \& Ribeiro, M. T. (2012). From Solid to Liquid: New Literacies to the Cultural Changes of Web 2.0. Comunicar, 19, 13 - 20. doi:10.3916/C38-2012-02-01

Areepattamannil, S., \& Khine, M. S. (2017). Early adolescents' use of information and communication technologies (ICTs) for social communication in 20 countries: Examining the roles of ICT-related behavioural and motivational characteristics. Computers in Human Behavior, 73, 263 - 272. doi: 10.1016/j.chb.2017.03.058

Bauman, Z. (2004). Modernidad líquida. México: Fondo de Cultura Económica.

Bawden, D. (2001). Information and Digital Literacies: A Review of Concepts. Journal of Documentation, 57, 218 259. doi:10.1108/EUM0000000007083

Bennett, S. J., Maton, K., \& Kervin, L. (2008). The 'digital natives' debate: A critical review of the evidence. British Journal of Educational Technology, 39, 775 - 786. doi:10.1111/j.1467-8535.2007. 00793.x

Bennett, S. J., \& Maton, K., (2010). Beyond the 'digital natives' debate: towards a more nuanced understanding of students' technology experiences. Journal of Computer Assisted Learning, 26, 321 - 331.

Bravo, M. L., \& Arrieta, J. J. (2005). El Método Delphi. Su implementación en una estrategia didáctica para la enseñanza de las demostraciones geométricas. Revista Iberoamericana de Educación, 35, 1-10. https://doi.org/10.35362/rie3672962

Bringué, X., \& Sádaba, Ch. (2009). La generación interactiva en España. Niños y adolescentes ante las pantallas. Barcelona: Ariel.

Buckingham, D. (2003). Media education. Literacy, learning and contemporary culture. Cambridge: Polity Press.

Buckingham, D. (2007). Media education goes digital: an introduction. Learning, Media and Technology, 32, 111119. doi: $10.1080 / 17439880701343006$

Buckingham, D., Banaji, S., Carr, D., Cranmer, S., \& Willett, R. (2005). The media literacy of children and young people: a review of the research literature. [Report] Retrieved from: http://eprints.ioe.ac.uk/145/

Cabra-Torres, F., \& Marciales-Vivas, G. P. (2009). Myths, Facts and Research on 'Digital Natives': A Review. Universitas Psychologica, 8, 323 - 338.

Celot, P. \& Pérez-Tornero, J. M. (Coords.) (2009). Study on Assessment Criteria for Media Literacy Levels - A comprehensive view of the concept of media literacy and an Understanding of how media literacy level in Europe Should Be Assessed. Brussels: European Commission. Retrieved from: http://ec.europa.eu/assets/eac/culture/library/studies/literacy-criteria-report_en.pdf

Chen, D.-T., Wu, J., \& Wang, Y.-M. (2011). Unpacking new media literacy. Journal on Systemics, Cybernetics and Informatics, 9, 84 - 88.

Considine, D., Horton, J. \& Morrman, G. (2009). Teaching and Reading the Millennial Generation Through Media Literacy. Journal of Adolescent \& Adult Literacy, 52, 471 - 481. doi:10.1598/JAAL.52.6.2

Correa, T. (2016). Digital skills and social media use: how Internet skills are related to different types of Facebook use among digital natives. Information, Communication \& Society, 19, 1095 - 1107. doi: 10.1080/ 1369118X.2015.1084023

De-Casas-Moreno, P., Tejedor-Calvo, S., \& Romero-Rodríguez, L. M. (2018). Micro-narratives on Instagram: analysis of the autobiographical storytelling and the projection of identities of the degrees in the field of communication. Prisma Social, 20, 40 - 57.

European Commission (2007). Comunicación de la Comisión al Parlamento Europeo, al Consejo, al Comité Económico y Social Europeo y al Comité de las Regiones. Un planteamiento europeo de la alfabetización 
mediática en el entorno digital. COM/2007/0833. Retrieved from: http://eurlex.europa.eu/legalcontent/ES/TXT/?uri= celex\%3A52007DC0833

Eshet, Y. (2004). Digital literacy: A conceptual framework for survival skills in the digital era. Journal of Educational Multimedia and Hypermedia, 13, 93 - 106.

Fedorov, A., \& Levitskaya, A. (2015). The framework of Media Education and Media Criticism in the Contemporary World: The opinion of International Experts. Comunicar, 23, 107 - 116. doi:10.3916/C45-2015-11

Ferrés, J., García Matilla, A., Aguaded, I., Fernández Cavia, J., Figueras, M., Blanes, M., ... Zarandona, E. (2011). Competencia mediática: Investigación sobre el grado de competencia de la ciudadanía en España. Madrid: Ministerio de Educación.

Ferrés, J. (2007). Competence in media studies: its dimensions and indicators. Comunicar, 15,100 - 107. https://doi.org/10.3916/C29-2007-14

Ferrés, J., Aguaded, I., \& García-Matilla, A. (2012). La competencia mediática de la ciudadanía española: dificultades y retos. Revista ICONO14, 10, 23 - 42. https://doi.org/10.7195/ri14.v10i3.201

Ferrés, J., \& Piscitelli, A. (2012). Media Competence. Articulated Proposal of Dimensions and Indicators. Comunicar, 19, 75 - 82. doi:10.3916/C38-2012-02-08

García-Ruiz, R., Ramírez, A., \& Rodríguez, M. M. (2014). Media literacy education for a new prosumer citizenship. Comunicar, 22, 15 - 23. doi:10.3916/C43-2014-01

Garson, G. D. (2013). Scales and Measures. Asheboro: Statistical Associates Publishers.

Gutiérrez, A., \& Tyner, K. (2012). Media education, media literacy and digital competence. Comunicar, 19, 31 - 39. doi:10.3916/C38-2012-02-03

Helsper, E. J., \& Eynon, R. (2010). Digital natives: where is the evidence? British Educational Research Journal, 36, 503 - 520. doi:10.1080/01411920902989227

Hernández, R., Fernández, C., \& Baptista, P. (2006). Metodología de la investigación. México: Mc Graw Hill

Hobbs, R. (2010). Digital and Media Literacy: A Plan of Action. A White Paper on the Digital and Media Literacy. Recommendations of the Knight Commission on the Information Needs of Communities in a Democracy. Washington, D.C.: The Aspen Institute. Retrieved from: https:/www.knightfoundation.org/media/uploads/ publication_pdfs/Digital_and_Media_Literacy_A_Plan_of_Action.pdf

Hobbs, R., \& Jensen, A. (2009). The Past, Present, and Future of Media Literacy Education. Journal of Media Literacy Education, 1, 1 - 11.

Howe, N., \& Strauss, W. (2000). Millennials rising: The next greatest generation. New York: Vintage Books.

Jenkins, H. P. I., Purushotma, R., Weigel, M., Clinton, K., \& Robison, A. J. (2009). Confronting the Challenges of Participatory Culture Media Education for the 21st Century. Cambridge: The MIT Press. Retrieved from: https://mitpress.mit.edu/sites/default/files/titles/free_download/9780262513623_Confronting_the_Challeng es.pdf

Jenkins, H. (2008). Convergence Culture. La cultura de la convergencia de los medios de comunicación. Barcelona: Paidós.

Johnson, L., Adams-Becker, S., Estrada, V., Freeman, A., Kampylis, P., Vuorikari, R., \& Punie, Y. (2014). Horizon Report Europe: 2014 Schools Edition. Luxembourg: Publications Office of the European Union, \& Austin, Texas: The New Media Consortium. Retrieved from: http://publications.jrc.ec.europa.eu/repository/ bitstream/JRC90385/2014-nmc-horizon-report-en_online.pdf

Kellner, D., \& Share, J. (2007). Critical media literacy, democracy, and the reconstruction of education. In D. Macedo \& S.R. Steinberg (Eds.), Media literacy: A reader (pp. 3-23). New York: Peter Lang Publishing.

Kellner, D., \& Share, J. (2005). Toward Critical Media Literacy: Core concepts, debates, organizations, and policy. Discourse: studies in the cultural politics of education, 26, 369 - 386. doi:10.1080/01596300500200169

Kim, J., \& Lee, G. (2013). Meaning of criteria and norms: Analyses and comparisons of ICT literacy competencies of middle school students. Computers \& Education, 64, 81 - 94. doi: 10.1016/j.compedu.2012.12.018

Koltay, T. (2011). The media and the literacies: media literacy, information literacy, digital literacy. Media, Culture \& Society, 33, 211 - 221. doi:10.1177/0163443710393382

Lee, L., Chen, D.-T., Li, J.-Y., \& Lin, T.-B. (2015). Understanding new media literacy: The development of a measuring instrument. Computers \& Education, 85, 84 - 93. doi: 10.1016/j.compedu.2015.02.006

Leurs, K., Omerović, E., Bruinenberg, H., \& Sprenger, S. (2018). Critical media literacy through making media: A key to participation for young migrants? Communications, 43, 427 - 450. doi:10.1515/commun-2018-0017

Livingstone, S. (2012). Critical reflections on the benefits of ICT in education. Oxford Review of Education, 38, 9-24. doi:10.1080/03054985.2011.577938

Livingstone, S. (2004) Media literacy and the challenge of new information and communication technologies. Communication Review, 7, 3 - 14. doi:10.1080/03054985.2011.577938 
Martens, H. (2010). Evaluating Media Literacy Education: Concepts, Theories and Future Directions. Journal of Media Literacy Education, 2, 1 - 22.

Masanet, M-J., Contreras-Pulido, P., \& Ferrés J. (2013). Highly qualified students? Research into media competence level of Spanish youth. Communication \& Society, 26, $217-234$.

Mason, L., \& Metzger, S. A. (2012). Reconceptualizing Media Literacy in the Social Studies: A Pragmatist Critique of the NCSS Position Statement on Media Literacy, Theory \& Research in Social Education, 40, 436 - 455. doi:10.1080/00933104.2012.724630

Masterman, L. (1993). La enseñanza de los medios de comunicación. Madrid: De la Torre.

McClure, C. R. (1994). Network literacy: A role for libraries. Information Technology and Libraries, 13, 115 - 125.

Moeller, S., Joseph, A., Lau, J., \& Carbo T. (2011). Towards Media and Information Literacy Indicators. Background Document of the Expert Meeting. Paris: UNESCO. Retrieved from: www.unesco.org/new/ fileadmin/MULTIMEDIA/HQ/CI/CI/pdf/unesco_mil_indicators_background_document_2011_final_en.pdf

OCDE (2018). The future of education and skills Education 2030. The future we want. Retrieved from: https://www.oecd.org/education/2030/E2030\%20Position\%20Paper\%20(05.04.2018).pdf

Nunnally, J. C., \& Bernstein, I. J. (1994). Teoría Psicométrica (3th Ed). México: McGraw-Hill Latinomericana.

Pérez-Rodríguez, M. A., Contreras-Pulido, P., \& Delgado-Ponce, Á. (2018). La competencia mediática en el escenario de convergencia digital. In L. M. Romero-Rodríguez and I. Aguaded (Ed.), Competencias mediáticas en medios digitales emergentes (pp. 29 - 47). Salamanca: Comunicación Social.

Pérez-Rodríguez, M. A., \& Delgado-Ponce, Á. (2012). From digital and audio-visual competence to media competence: Dimensions and indicators. Comunicar, 39, 25-34. https://doi.org/10.3916/C39-2012-02-02

Pérez-Rodríguez, M. A., Ramírez-García, A., \& García-Ruiz, R. (2015). La competencia mediática en Educación Infantil. Análisis del nivel de desarrollo en España. Universitas Psychologica, 14, 619 - 630. doi: 10.11144/Javeriana.upsy14-2.cmei

Pérez-Tornero, J. M. (Coord.) (2013). Midiendo la alfabetización mediática en Europa 2005-2010. Barcelona: Universitat Autònoma de Barcelona.

Pérez-Tornero, J. M., \& Martínez-Cerdá, J. F. (2011). Hacia un sistema supranacional de indicadores mediáticos. Infoamérica, 5, 39 - 57. Retrieved from: www.infoamerica.org/icr/icr_05.htm

Peterson, R. A. (1994). A meta-analysis of Cronbach's coefficient alpha. Journal of Consumer Research, 21, 381-391.

Potter, W. J. (2004). Argument for the need for a cognitive theory of media literacy. America Behavioral Scientist, 48, 266 - 272. doi: $10.1177 / 0002764204267274$

Potter, W. J. (2010). The state of media literacy. Journal of Broadcasting \& Electronic Media, 54, 675 - 696. doi:10.1080/08838151.2011.521462

Prensky, M. (2001). Digital natives, digital immigrants. On the Horizon, 9, 1 - 6. doi:10.1108/10748120110424843

Ramírez-García, A., \& González-Fernández, N. (2016). Media competence of teachers and students of Compulsory Education in Spain. Comunicar, 49, 49 - 58. https://doi.org/10.3916/C49-2016-05

Rohatgi, A., Scherer, R., \& Hatlevik, O.E. (2016). The role of ICT self-efficacy for students' ICT use and their achievement in a computer and information literacy test. Computers \& Education, 102, 103 - 116. doi: 10.1016/j.compedu.2016.08.001

Romero-Rodríguez, L. M., Torres-Toukoumidis, Á., Pérez-Rodríguez, M. A., \& Aguaded, I. (2016). Analfanautas y la cuarta pantalla: ausencia de infodietas y de competencias mediáticas e informaciones en jóvenes universitarios latinoamericanos. Fonseca, Journal of Communication, 2, 11-25. doi: 10.14201/fjc2016121125

Roy, N., Gareau, A., \& Poellhuber, B. (2018). Les natifs du numérique aux études: enjeux et pratiques [The Digital Natives in Education: Issues and Practices]. Canadian Journal of Learning and Technology / La revue canadienne de l'apprentissage et de la technologie, 44. Retrieved from https://www.cjlt.ca/index.php/cjlt/article/view/27558

Rowlands, I., Nicholas, D., Williams, P., \& Huntington, P. (2008). Google generation: The information behaviour of the researcher of the future. Aslib Proceedings. Bradford, 60, 290 - 310. doi:10.1108/00012530810887953

Scherer, R., Rohatgi, A., \& Hatlevik, O. E. (2017). Students' profiles of ICT use: Identification, determinants, and relations to achievement in a computer and information literacy test. Computers in Human Behavior, 70, 486499. doi: 10.1016/j.chb.2017.01.034

Scolari, C. (Ed.) (2018). Adolescentes, medios de comunicación y culturas colaborativas. Aprovechando las competencias transmedia de los jóvenes en el aula. Barcelona: Universitat Pompeu Fabra.

Kim, S. (2019). ICT/media uses and college entry for students from diverse Backgrounds. Educational Media International, 56, 44-58. doi: 10.1080/09523987.2019.1583462

Tapscott, D. (1999). Educating the Net Generation. Educational Leadership, 56, 6 - 11.

Thompson, P. (2013). The digital natives as learners: Technology use patterns and approaches to learning. Computers 
\& Education, 65, 12 - 33. doi: 10.1016/j.compedu.2012.12.022

Van Deursen, A., \& Van Dijk, J. (2010). Internet skills and digital divide. New Media and Society, 13, 893-911. doi:10.1177/1461444810386774

Velagapudi, V., \& Menon, S. (2018). Student behaviour in technology integrated classrooms. 2018 IEEE Ninth International Conference on Technology for Education (T4E). doi:10.1109/T4E.2018.00029

Yildiz Durak, H., \& Saritepeci, M. (2019). Modelling the effect of new media literacy levels and social media usage status on problematic internet usage behaviours among high school students. Education and Information Technologies, 1 - 19. https://doi.org/10.1007/s10639-019-09864-9. 